\title{
Efficiency of nutrient management in controlling eutrophication of running waters in the Middle Danube Basin
}

\author{
Vera Istvánovics • Márk Honti
}

Received: 29 November 2010/Revised: 16 December 2011/Accepted: 23 December 2011/Published online: 15 January 2012 (c) Springer Science+Business Media B.V. 2012

\begin{abstract}
Nutrient emission dropped significantly during the last two decades in the Danube Basin. To assess the effect of reduced nutrient loads on the trophic status of running waters, this regional study analyzed the relationships between nutrients $(\mathrm{P}$ and $\mathrm{N})$ and suspended chlorophyll (Chl) using long-term monitoring data in Hungary. Including the upstream catchments of trans-boundary rivers, the study covered an approximate area of $400,000 \mathrm{~km}^{2}$, equivalent to the half of the entire Danube catchment. Decadal median Chl was unrelated to $\mathrm{P}$ and $\mathrm{N}$ concentrations in the whole data set and weakly related to total P (TP) at natural-moderately polluted (N-MP) sites, which were distinguished from highly polluted (HP) sites by using cutoff values for chloride, chemical oxygen demand and TP. At both the N-MP sites and most of the HP
\end{abstract}

Handling editor: Luigi Naselli-Flores

V. Istvánovics $(\bowtie) \cdot$ M. Honti

Water Resources Management Group of the Hungarian Academy of Sciences, Department of Environmental and Sanitary Engineering, Budapest University of Technology and Economics, Müegyetem rkp. 3, Budapest 1111, Hungary

e-mail: istvera@goliat.eik.bme.hu

M. Honti

e-mail: mark@vkkt.bme.hu

Present Address:

M. Honti

EAWAG, Überlandstrasse 133, 8600 Dübendorf, Switzerland sites, Chl increased with channel length. This indicated that water residence time was a more important determinant of $\mathrm{Chl}$ than nutrients. Nutrient concentrations showed a significant downward trend in time at half of our sites. With a nearly equal frequency, a parallel trend might or might not occur in Chl. The apparent efficiency of nutrient management was expressed as the quotient of the slopes of linear trends in Chl and nutrients. At sites within $150 \mathrm{~km}$ from source, this efficiency was marginal. In larger rivers, efficiency improved steeply. The highest efficiency was observed in the downstream reach of the Danube (upstream length $>1,300 \mathrm{~km}$ ) where $\mathrm{P}$ availability might frequently limit algal growth. The results suggest that eutrophication management in rivers should be based on Chl response functions, rather than universal nutrient criteria. Four $\mathrm{Chl}$ response classes were identified based on the observed longitudinal $\mathrm{P}$ and Chl gradients.

Keywords Sestonic chlorophyll $\cdot$ River size · Water residence time $\cdot$ Nutrient management efficiency · Chlorophyll response functions . Water Framework Directive

\section{Introduction}

Eutrophication remains a significant threat to biodiversity and compromises ecological services in aquatic ecosystems. Reduction of the external nutrient 
loads is the key measure to manage eutrophication in standing waters (Sas, 1989; Smith, 2003) where the algal biomass capacity is typically set by nutrients under pristine conditions (Vollenweider \& Kerekes, 1982; Reynolds, 1992). The relationship between nutrient supply and eutrophication is much less clear in running waters.

From headwater streams to the mouth, river networks present dynamically changing physical gradients to biota, including algae. Concepts depict these gradients either being smooth and continuous along the flow (Vannote et al., 1980), or patchy and discontinuous at various spatial and temporal scales in longitudinal, lateral, and vertical dimensions (Thorp et al., 2006). Irrespective of the spatial layout of the physical habitat templates, riverine phytoplankton must cope with short water residence times (WRT) and rapid flushing that are determined by channel retentivity and stochastic flow variability (Reynolds \& Descy,1996). In a natural river network with moderate slopes, water residence time is roughly proportional to the hydrologic distance from a given point to the mouth, allowing a monotonous downstream increase in phytoplankton abundance. The typical longitudinal profile of light availability, however, is not monotonous. Headwater streams of forested catchments can be heavily shaded by the terrestrial canopy cover either seasonally or year-round, while in the deep channels of large lowland rivers inorganic turbidity often restricts light availability (Vannote et al., 1980; Reynolds \& Descy, 1996; Dokulil, 2006; Istvánovics et al., 2010). Thus, the highest autotrophic productivity is expected in medium-sized rivers and in large floodplain rivers tightly connected with backwater habitats (Vannote et al., 1980; Hein et al., 2003, Thorp et al., 2006). Physical gradients along the river network govern the distribution of various algae with periphyton dominance in headwater streams, gradual appearance of phytoplankton in streams of 3rd order or higher, and prevalence of true phytoplankton in large rivers (Vannote et al., 1980). Short WRT and low-light availablity also selects for small, fast growing, and low-light adapted species of algae (Reynolds et al., 1994; Reynolds \& Descy, 1996).

While basic ecological theory provides a clear explanation for the effects of physical boundary conditions in river networks, we lack a general model on the role of nutrients in regulating stream productivity and eutrophication. Nutrient concentrations in pristine rivers vary in a wide range due to differences in geology, climate, type, and topology of terrestrial ecosystems, the relative contribution of various input sources (e.g., surface runoff, subsurface flow, atmospheric deposition), as well as due to the variability in abiotic and biotic mechanisms of in-stream nutrient transformations (Meybeck, 1982; Froelich, 1988; Stutter et al., 2010). In naturally fertile temperate catchments concentrations of nutrients under pristine conditions (nitrate up to $160 \mathrm{mg} \mathrm{N} \mathrm{m}^{-3}$, ammonium up to $60 \mathrm{mg} \mathrm{N} \mathrm{m}^{-3}$, soluble reactive $\mathrm{P}$ up to $15 \mathrm{mg} \mathrm{P} \mathrm{m}^{-3}$; Meybeck, 1982) exceed the values, which are thought to be potentially limiting for algal growth (Reynolds, 1992). Yet, several comparative studies detected nutrient limitation of algal growth or biomass in rivers. A review of stream enrichment experiments suggested that nutrient limitation of growth was common and widespread (Smith et al., 1999). N and P were equally likely to limit the biomass of periphyton (Francoeur, 2001). Significant relationships were found between the concentration of total phosphorus (TP) and chlorophyll $a(\mathrm{Chl})$ in various sets of North-American rivers (Basu \& Pick, 1996; van Nieuwenhuyse \& Jones, 1996). Short WRT interfered with nutrient limitation and reduced the algal yield per unit $\mathrm{P}$ compared to lakes and reservoirs (Søballe \& Kimmel, 1987) and thus, P-specific yield of algae increased in proportion to catchment size (van Nieuwenhuyse \& Jones, 1996; Royer et al., 2008). Nutrient criteria were suggested to prevent undesirable proliferation of periphyton and phytoplankton in streams and rivers (Dodds \& Welch, 2000; Biggs, 2000; Dodds, 2006).

The Water Framework Directive of the European Union (WFD) requires achieving 'good ecological status' in natural water bodies by 2015 , and eutrophication control is a focal issue (Neal et al., 2008). Although a substantial human-induced increase in both nutrient concentrations and algal biomass have been observed in rivers (Meybeck, 1982; Billen et al., 2007; Sabater et al., 2008; Honti et al., 2010), very few systematic studies examined the effect of large-scale nutrient reduction on the trophic status of running waters. Considering the lack of a well-established river eutrophication model similar to Vollenweider's model of lake eutrophication (Vollenweider \& Kerekes, 1982), there is a need for empirical validation of nutrient criteria suggested for eutrophication management in rivers.

In the Danube catchment, $\mathrm{P}$ emission increased from 82 to $115 \mathrm{kt} \mathrm{P}$ year $^{-1}$ between 1975 and 1990, 
followed by a decrease to $68 \mathrm{kt} \mathrm{P}$ year ${ }^{-1}$ by 2000 . N emission increased from 750 to $910 \mathrm{kt} \mathrm{N}^{\mathrm{N} e a r^{-1}}$ and then returned to the level of 1975 in the same periods (Schreiber et al., 2005; ICPDR, 2005). About 75 and $40 \%$ of the decrease in $\mathrm{P}$ and $\mathrm{N}$ emissions, respectively, was due to improved sewage treatment (Schreiber et al., 2005; Csathó et al., 2007). From 1990, fertilizer application rates have dropped in the Central and Eastern European (CEE) countries to $5 \mathrm{~kg} \mathrm{P} \mathrm{ha}^{-1}$ in 2000. This rate was equivalent to half of the average in the EU15 countries (EU members prior to 2004), and gradually resulted in the present negative $\mathrm{P}$ balance of agricultural soils (Csathó et al., 2007). The $\mathrm{N}$ balance remained positive (200-250 $\mathrm{kg} \mathrm{N}^{-1}$ ), but $80-85 \%$ lower than the average in the EU15 countries (Csathó \& Radimszky, 2011). A $10 \%$ decrease in the cultivated area in Hungary (Hungarian Central Statistical Office, HCSO; http://portal.ksh.hu) further contributed to the reduction of diffuse loads.

We analyzed the relationship between nutrient ( $P$ and $\mathrm{N}$ ) and $\mathrm{Chl}$ concentrations using monitoring data collected from 243 sites in 127 streams and rivers across Hungary between 1975 and 2006. The substantial decrease in nutrient emission during this period allowed us to assess the effect of nutrient reduction on the trophic status of rivers and streams in the Middle Danube Basin.

\section{Materials and methods}

Study area

Hungary is a lowland country in the Carpathian Basin. Of its area $\left(93,000 \mathrm{~km}^{2}\right), 68 \%$ is situated below an elevation of $200 \mathrm{~m}$ a.s.l. and only $2 \%$ lies above $400 \mathrm{~m}$ a.s.l. (Fig. 1). Loose, clastic Pleistocene and Miocene deposits cover $90 \%$ of the country with a roughly equal share of fluvial and Aeolian fills (Ódor et al., 1997). Fertile, thick loess soils provide a high agro-ecological potential (Catt, 2001). Forests, grasslands and arable land make up 20,10, and 50\% of the area, respectively (HCSO). Median TP content of deep floodplain deposits (460 $\mu \mathrm{g} \mathrm{P} \mathrm{g}^{-1}$ in the 50-60 cm layer, Ódor et al., 1997) indicates that the geochemical background is almost twice as high as the European median $\left(240 \mu \mathrm{g} \mathrm{P} \mathrm{g}^{-1}\right.$; Salminen et al., 2005). Human impact resulted in a 15-25\% enrichment of $\mathrm{P}$ in the surface floodplain deposits (0-10 cm layer; Ódor et al., 1997). As a long- term average, most of the precipitation $\left(58 \mathrm{~km}^{3} \mathrm{year}^{-1}\right)$ evaporates, so the total outflow from Hungary $\left(120 \mathrm{~km}^{3}\right.$ year $\left.^{-1}\right)$ is only $5 \%$ more than the inflow.

Mean population density is 107 persons $\mathrm{km}^{-2}$, slightly lower than the mean for the entire Danube catchment. Including the upstream catchments of trans-boundary rivers, our regional study covered an area of approximately $400,000 \mathrm{~km}^{2}$. This is equivalent to half of the entire Danube catchment.

\section{Water Quality Database}

The National Water Quality Database (NWQD) contained data for 243 sites in 127 rivers and streams that ranged from 2nd order streams to River Danube (10th order; Fig. 1; Table 1). Geographical distribution of monitoring sites roughly corresponded to drainage density, which is particularly low in the alluvial plain between the Danube and the Tisza Rivers. Besides drainage density, socio-economic priorities were also considered when designing the monitoring network. Priorities included (i) inflow and outflow sections of trans-boundary streams and rivers; (ii) inflows to Lake Balaton, the largest $\left(600 \mathrm{~km}^{2}\right)$ Hungarian lake; and (iii) upstream and downstream sections of rivers at large settlements.

About two-thirds of streams and rivers were monitored at a single site, usually close to their receiving waters. In contrast, the Danube and its largest tributary, the Tisza River were sampled at 14 and 15 sites, respectively. Multiple sites from the same river were treated as independent during the statistical analysis. At the majority of sites, subsurface water samples were taken from the thalweg. In the largest rivers, a few cross-sections were sampled at three locations. In the latter case, the cross-sectional average was used to characterize the site. Sampling frequency ranged from weekly to monthly. Previous comparative studies typically relied on seasonal data (Basu \& Pick, 1996; van Nieuwenhuyse \& Jones, 1996). To retain comparability with these studies, we limited the data analysis to the measurements obtained between 1 May and 30 September each year.

Sample analyses were done in 12 regional laboratories accredited according to the EN ISO/EC 17025 European standard. We used the following water quality variables: chlorophyll $a(\mathrm{Chl}$; extraction in hot ethanol, uncorrected for phaeopigments), soluble reactive $\mathrm{P}$ (SRP, molybdenum blue method), total 


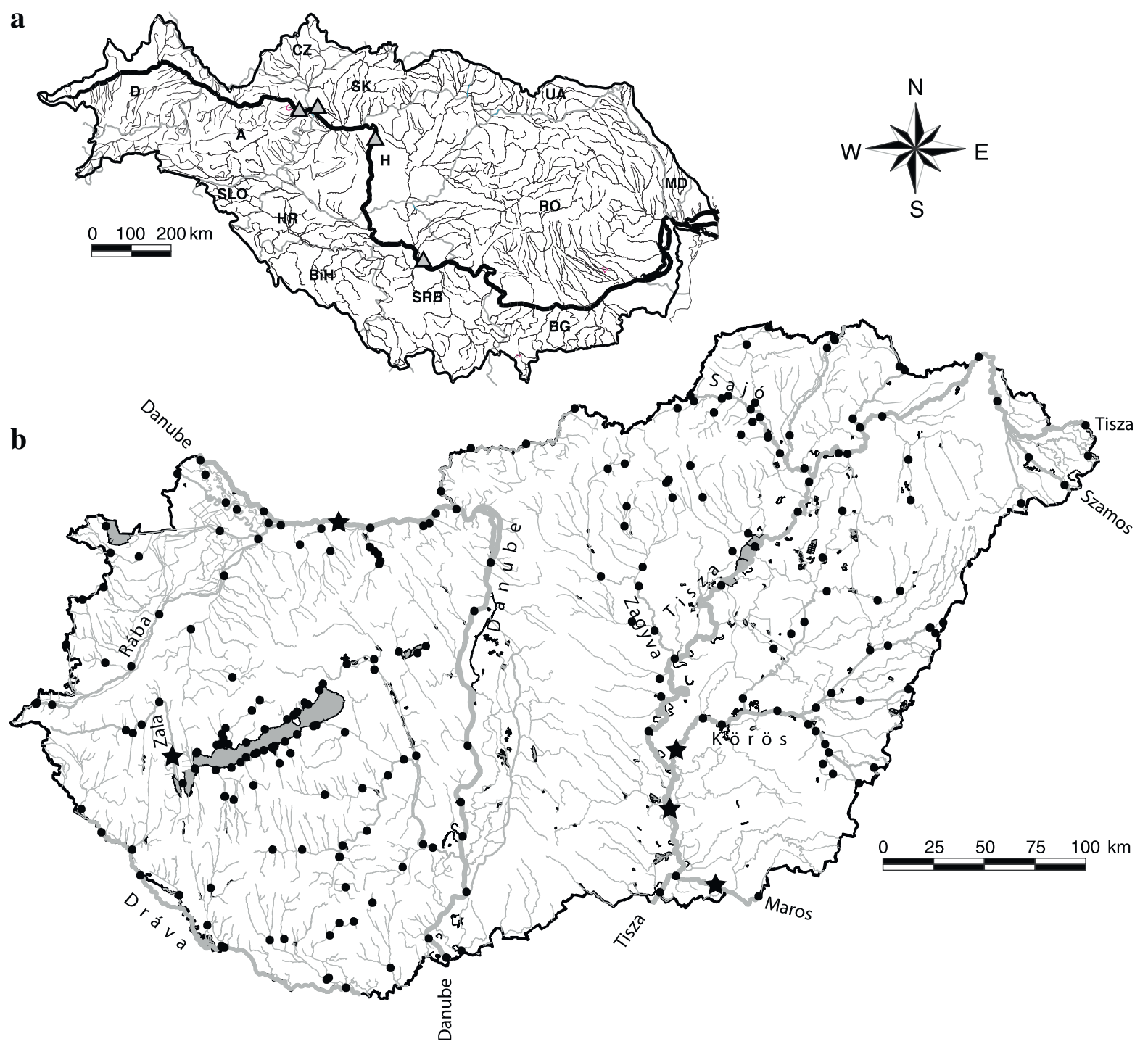

Fig. 1 The Danube catchment (a) and the water quality monitoring network in streams and rivers in Hungary (b). a Triangles indicate capitals situated on the banks of the Danube. Countries in the Danube catchment: $D$ Germany,

phosphorus (TP; measured as SRP after $\mathrm{H}_{2} \mathrm{SO}_{4}-\mathrm{H}_{2} \mathrm{O}_{2}$ digestion), nitrate (the salicylate method), nitrite (the sulphanilamide method), ammonium (indophenol blue method), total nitrogen (TN, the sum of total Kjeldhal N, nitrate and nitrite), DIN (the sum of nitrate, nitrite and ammonium), $\mathrm{pH}$, specific conductivity, $\mathrm{Ca}, \mathrm{Mg}$ (complexometric titration), $\mathrm{K}, \mathrm{Na}$ (flame emission photometry), $\mathrm{Cl}$ (argentometric titration), sulfate (barium precipitation method), oxygen saturation (Winkler method with field addition of reagents), suspended solids (gravimetry), biological
A Austria, SLO Slovenia, CZ Czech Republic, $H R$ Croatia, $B i H$ Bosnia and Herzegovina, $S K$ Slovakia, $S R B$ Serbia, $H$ Hungary, $B G$ Bulgaria, UA Ukraine, RO Romania, $M O$ Moldavia. b Stars indicate sites where $\mathrm{Chl}$ data were available for three decades

oxygen demand $\left(\mathrm{BOD}_{5}\right)$, and chemical oxygen demand (COD, dichromate method).

Hydrological data

Upstream length $(L, \mathrm{~km})$ was calculated at each site from the total length of the main channel (http://www. euvki.hu/euwfd/index.html) and the position of the sampling site. In about $80 \%$ of cases, the NWQD included flow $\left(Q, \mathrm{~m}^{3} \mathrm{~s}^{-1}\right)$ during the sampling. Upstream catchment area $\left(A, \mathrm{~km}^{2}\right)$ was known at 192 
Table 1 Summary of morphological and water quality characteristics

\begin{tabular}{lllll}
\hline Parameter & Median & Minimum & Maximum & $n$ \\
\hline$L(\mathrm{~km})$ & 46.3 & 1.2 & 1,417 & 243 \\
$A\left(\mathrm{~km}^{2}\right)$ & 1,964 & 4.9 & 209,064 & 192 \\
$Q\left(\mathrm{~m}^{3} \mathrm{~s}^{-1}\right)$ & 2.6 & 0.002 & 2,460 & 290 \\
$\mathrm{SRP}\left(\mathrm{mg} \mathrm{P} \mathrm{m}^{-3}\right)$ & 104 & 9 & 4,205 & 346 \\
$\mathrm{TP}\left(\mathrm{mg} \mathrm{P} \mathrm{m}^{-3}\right)$ & 225 & 40 & 4,450 & 346 \\
$\mathrm{DIN}\left(\mathrm{mg} \mathrm{N} \mathrm{m}^{-3}\right)$ & 1,790 & 136 & 46,310 & 346 \\
$\mathrm{TN}\left(\mathrm{mg} \mathrm{N} \mathrm{m}^{-3}\right)$ & 2,800 & 695 & 31,300 & 254 \\
$\mathrm{DIN}: \mathrm{SRP}(\mu \mathrm{g} \mathrm{N}$ & 15.8 & 0.2 & 1,310 & 346 \\
$\left.\quad[\mu \mathrm{g} \mathrm{P}]^{-1}\right)$ & & & & \\
Chl $\left(\mathrm{mg} \mathrm{m}^{-3}\right)$ & 9.2 & 0.7 & 237.4 & 346 \\
\hline
\end{tabular}

$L$ upstream length, $A$ upstream catchment area, $Q$ decadal summer median discharge, $n$ number of sites. Water quality characteristics are decadal summer median values

gauges that did not always coincide with the site of water quality sampling. As expected (Leopold et al., 1964), $L$ correlated with both $A(\log (L)=0.001 \pm$ $0.043+0.59 \pm 0.01 \cdot \log (A), \quad r^{2}=0.92, \quad n=192$, $P<0.001)$ and median flow over a 10 -year period $\left(\log (Q)=-2.98 \pm 0.08+1.90 \pm 0.04 \cdot \log (L), r^{2}=\right.$ $0.88, n=291, P<0.001)$. Average WRT was estimated using the model of Walks (2007) from $L$ and median $Q$ over a 10 -year period.

\section{Eutrophication models}

The statistical model of Van Nieuwenhuyse \& Jones (1996) was used to estimate a benchmark Chl concentration from TP. Besides this river eutrophication model, we also applied the TP versus $\mathrm{Chl}$ model of Jackson et al. (2007) from their study on shallow Danish lakes. Since the Chl yield per unit TP is typically lower in rivers than in standing waters, the latter model could provide a site-specific estimate of the highest limit of productivity.

\section{Statistical analysis}

Three approaches were used: (i) comparison among sites, (ii) regression analysis within individual sites, and (iii) trend analysis within individual sites. To compare sites, data were pooled into 10-year-long groups (1977-1986, 1987-1996, 1997-2006). Decadal pooling was a compromise between keeping the longterm trends and providing a reasonable sample size for the estimation of medians. The three periods approximately coincided with the developing, collapsing and re-structuring phases of economy in the CEE countries. Monitoring data were available for 6, 41 and 57 rivers in 1977-1986, 1987-1996, and 1997-2006, respectively. There were at least 40 individual records at each site and period. Data from different periods were treated independent even if they came from the same site. We included into the analysis data from 35 additional sites which were monitored only between 2004 and 2006, provided that the minimal sample size was 30 .

Sites were classified as "heavily polluted" (HP) and "natural or moderately polluted" (N-MP) in each period by comparing decadal median values of $\mathrm{COD}$, chloride and TP with cutoff values. A site qualified as HP if any of the following criteria was met: $\mathrm{COD} \geq 20 \mathrm{~g} \mathrm{O}_{2} \mathrm{~m}^{-3}$; $\mathrm{Cl}^{-} \geq 35 \mathrm{mg} \mathrm{m}^{-3}$; TP $\geq 150 \mathrm{mg} \mathrm{P} \mathrm{m}^{-3}$. Other water quality components were not used in the classification. We used relatively high cutoff values because several streams drain peat areas (high natural COD), about $6 \%$ of soils are saline in Hungary (high natural $\mathrm{Cl}^{-}$), and the geochemical background of P is high (Ódor et al., 1997).

Correlations between the nutrients (except TP), Chl and several other water quality variables were calculated using log-transformed data. Simple and stepwise multiple regressions were used to evaluate the relationships between decadal median values of independent variables (nutrients, $L$, and $Q$ ) and $\mathrm{Chl}$ in the full data set and at the N-MP sites.

To examine the nutrient versus $\mathrm{Chl}$ and $Q$ versus Chl relationships within individual sites, we computed summer (1 May to 30 September) median values for each year. There were 160 sites where a median could be derived for each variable. At some sites the associated uncertainty was high due to the low number of available data. We tested linear, logarithmic, exponential, and power regression functions on log-transformed variable pairs and the best fitting type of model was accepted to describe the relationship.

Long-term linear trends in nutrient concentrations and $\mathrm{Chl}$ were analyzed using summer median values for each year at 184 sites. When and wherever a significant $(P<0.05)$ trend in $\mathrm{Chl}$ was identified, the trend in nutrients (TP, SRP, TN, and DIN) was examined within the same period. We assumed that $\mathrm{Chl}$ immediately responded to a change in nutrient concentrations (delay $<1$ year). The apparent efficiency of 
nutrient management ( $\mu \mathrm{g}$ Chl $[\mu \mathrm{g} \mathrm{P}]^{-1} ; \mu \mathrm{g}$ Chl $[\mu \mathrm{g} \mathrm{N}]^{-1}$ ) was defined as the quotient of the slopes of significant linear trends in $\mathrm{Chl}$ and the respective nutrient.

\section{Results}

Comparison among sites

The median concentration of nutrients and $\mathrm{Chl}$ spanned over two orders of magnitude in the different periods (Table 1). The 10 highest TP, SRP, and Chl concentrations were found in middle-sized streams (median $L=40 \mathrm{~km}$, stream order 4 to 5$)$. The respective $L$ value was significantly shorter $(L=16 \mathrm{~km})$ for DIN. Median DIN to SRP mass ratio was 15.8 with large variability among sites (Table 1). Relative DIN scarcity (DIN:SRP <7) was coupled to high DIN concentration ( $>200 \mathrm{mg} \mathrm{N} \mathrm{m}^{-3}$ ) with a single exception representing the outflow of a large, anaerobic wetland. In contrast, relative SRP scarcity (DIN:SRP $>7$ ) was typical of sites with low SRP concentration $\left(<20 \mathrm{mg} \mathrm{P} \mathrm{m}^{-3}\right)$.

Higher-order rivers were generally less polluted than medium ones. Major ions were inversely related to $L$ (Table 2). Nitrite, TN, and SRP also tended to decrease with $Q$ and $L$, with the former correlation being stronger.

High TP concentrations were associated with elevated $\mathrm{N}$ concentrations (Table 2). There was a clear association between high nutrient concentrations and sewage indicators. TP, ammonium, and nitrite showed similarly strong positive correlations with ions that originate primarily from sewage $\left(\mathrm{Na}^{+}, \mathrm{Cl}^{-}\right)$, as well as with chemical and biological oxygen demand (COD and $\mathrm{BOD}_{5}$ ). High TP and reduced inorganic $\mathrm{N}$ concentrations coincided with a significantly lower $\mathrm{O}_{2}$ saturation.

Table 2 Correlation coefficients of significant $(P<0.001)$ correlations between upstream length $(L)$ and decadal summer median values of water quality components

\begin{tabular}{|c|c|c|c|c|c|}
\hline Variable & $L(\mathrm{~km})$ & $\begin{array}{l}\mathrm{TP} \\
\left(\mathrm{mg} \mathrm{P} \mathrm{m}^{-3}\right)\end{array}$ & $\begin{array}{l}\text { DIN } \\
\left(\mathrm{mg} \mathrm{N} \mathrm{m}^{-3}\right)\end{array}$ & $\begin{array}{l}\mathrm{NH}_{4}+\mathrm{NO}_{2} \\
\left(\mathrm{mg} \mathrm{N} \mathrm{m}^{-3}\right)\end{array}$ & $\begin{array}{l}\text { Chl } \\
\left(\mathrm{mg} \mathrm{m}^{-3}\right)\end{array}$ \\
\hline $\mathrm{pH}$ & -0.21 & - & - & -0.31 & - \\
\hline Conductivity $\left(\mu \mathrm{S} \mathrm{cm}^{-1}\right)$ & -0.68 & 0.55 & 0.40 & 0.49 & - \\
\hline $\mathrm{Ca}^{2+}\left(\mathrm{g} \mathrm{m}^{-3}\right)$ & -0.62 & 0.42 & 0.47 & 0.35 & - \\
\hline $\mathrm{Mg}^{2+}\left(\mathrm{g} \mathrm{m}^{-3}\right)$ & -0.74 & 0.39 & 0.25 & 0.26 & - \\
\hline $\mathrm{K}^{+}\left(\mathrm{g} \mathrm{m}^{-3}\right)$ & -0.52 & 0.63 & 0.46 & 0.61 & - \\
\hline $\mathrm{Na}^{+}\left(\mathrm{g} \mathrm{m}^{-3}\right)$ & -0.35 & 0.63 & 0.27 & 0.56 & - \\
\hline $\mathrm{Cl}^{-}\left(\mathrm{g} \mathrm{m}^{-3}\right)$ & -0.29 & 0.58 & 0.40 & 0.58 & 0.21 \\
\hline $\mathrm{HCO}_{3}^{-}\left(\mathrm{g} \mathrm{m}^{-3}\right)$ & -0.72 & 0.50 & 0.25 & 0.34 & - \\
\hline $\mathrm{SO}_{4}^{2-}\left(\mathrm{g} \mathrm{m}^{-3}\right)$ & -0.54 & 0.40 & 0.43 & 0.42 & - \\
\hline Susp. solids $\left(\mathrm{g} \mathrm{m}^{-3}\right)$ & 0.33 & 0.20 & 0.29 & 0.21 & 0.47 \\
\hline $\mathrm{NH}_{4}-\mathrm{N}\left(\mathrm{mg} \mathrm{N} \mathrm{m}^{-3}\right)$ & - & 0.67 & 0.46 & 0.98 & - \\
\hline $\mathrm{NO}_{2}-\mathrm{N}\left(\mathrm{mg} \mathrm{N} \mathrm{m}^{-3}\right)$ & -0.18 & 0.67 & 0.72 & 0.80 & - \\
\hline $\mathrm{NO}_{3}-\mathrm{N}\left(\mathrm{mg} \mathrm{N} \mathrm{m}^{-3}\right)$ & - & - & 0.87 & 0.18 & - \\
\hline $\operatorname{DIN}\left(\mathrm{mg} \mathrm{N} \mathrm{m}^{-3}\right)$ & - & 0.44 & - & 0.55 & - \\
\hline $\mathrm{TN}\left(\mathrm{mg} \mathrm{N} \mathrm{m}^{-3}\right)$ & -0.41 & 0.46 & 0.80 & 0.50 & - \\
\hline $\mathrm{SRP}\left(\mathrm{mg} \mathrm{P} \mathrm{m}^{-3}\right)$ & -0.21 & 0.94 & 0.49 & 0.74 & - \\
\hline $\mathrm{TP}\left(\mathrm{mg} \mathrm{P} \mathrm{m}^{-3}\right)$ & -0.20 & - & 0.44 & 0.72 & - \\
\hline $\mathrm{O}_{2}$ saturation $(\%)$ & 0.23 & -0.45 & - & -0.46 & - \\
\hline $\mathrm{BOD}_{5}\left(\mathrm{~g} \mathrm{O}_{2} \mathrm{~m}^{-3}\right)$ & - & 0.50 & 0.19 & 0.60 & 0.56 \\
\hline $\operatorname{COD}\left(\mathrm{g} \mathrm{O}_{2} \mathrm{~m}^{-3}\right)$ & -0.28 & 0.57 & - & 0.49 & 0.50 \\
\hline$L(\mathrm{~km})$ & - & -0.20 & - & -0.20 & 0.32 \\
\hline
\end{tabular}

With the exception of $\mathrm{pH}, \log$-transformed data were used. The number of data points was 254 for $\mathrm{TN}$, and 346 for other variables 
Despite the coupled abundance of various nutrient forms, median Chl was not significantly related to any nutrient forms. Although both some nutrients and $\mathrm{Chl}$ were significantly correlated to $\mathrm{COD}, \mathrm{BOD}_{5}$, and chloride, the direct correlation remained weak. The weak positive correlation between $L$ and $\mathrm{Chl}$ was indicative of the important role of WRT in phytoplankton development.

Chl showed large variance regardless the value of TP, TN, and $Q$ (Fig. 2). Consequently, the TP versus Chl model of van Nieuwenhuyse \& Jones (1996) predicted Chl poorly (Fig. 2a). Although at $80 \%$ of sites $\mathrm{Chl}$ was lower than predicted by this model, there were a few sites where Chl exceeded the productivity of shallow Danish lakes (Jackson et al., 2007).

Heavily polluted sites might distort the relationship between nutrients and $\mathrm{Chl}$, since algal growth may not keep pace with a sudden excess of nutrients. So we repeated the analysis after excluding the HP sites. The overwhelming majority of sites (84\%) were classified as HP, including nearly each site prior to 1997-2006 (Table 3). The $56 \mathrm{~N}-\mathrm{MP}$ sites were situated in 23 streams and rivers. HP rivers were typically much shorter than N-MP ones (6.5 times difference in median $L$ ). Due to the strong correlations between different nutrient forms, N-MP sites had significantly lower $(P<0.001)$ concentrations of those nutrient forms, which were not used in the HP-N-MP classification (each N species and SRP). Significant correlations remained similar between variables at HP sites (not shown) to those found for all sites (Table 2). At the N-MP sites, TP covaried with nitrite ( $r=0.51, P<0.001)$ but was not anymore significantly related to other $\mathrm{N}$ species.

Although a weak positive correlation was found between TP and Chl at the N-MP sites $(r=0.45$, $n=56, P<0.001$ ), a considerable deviation was obvious from the model of van Nieuwenhuyse \& Jones (1996; Fig. 3a). At the same time, Chl was more strongly related to $L$ at these sites (Fig. $3 b$ ) than in the whole data set (Table 2). An exponential model yielded the best fit. No improvement could be achieved by multiple regression models with stepwise including SRP, TP, DIN or the DIN to SRP ratio. At nearly two-thirds of the HP sites, Chl varied within the 95\% confidence interval of the $L$ versus Chl relationship obtained for the N-MP sites. At the remaining HP sites, Chl exceeded the upper confidence limit.

At the N-MP sites, the Chl yield per unit TP averaged at $0.11 \pm 0.11 \mu \mathrm{g} \mathrm{Chl}[\mu \mathrm{g} \mathrm{P}]^{-1}$ (range 0.013
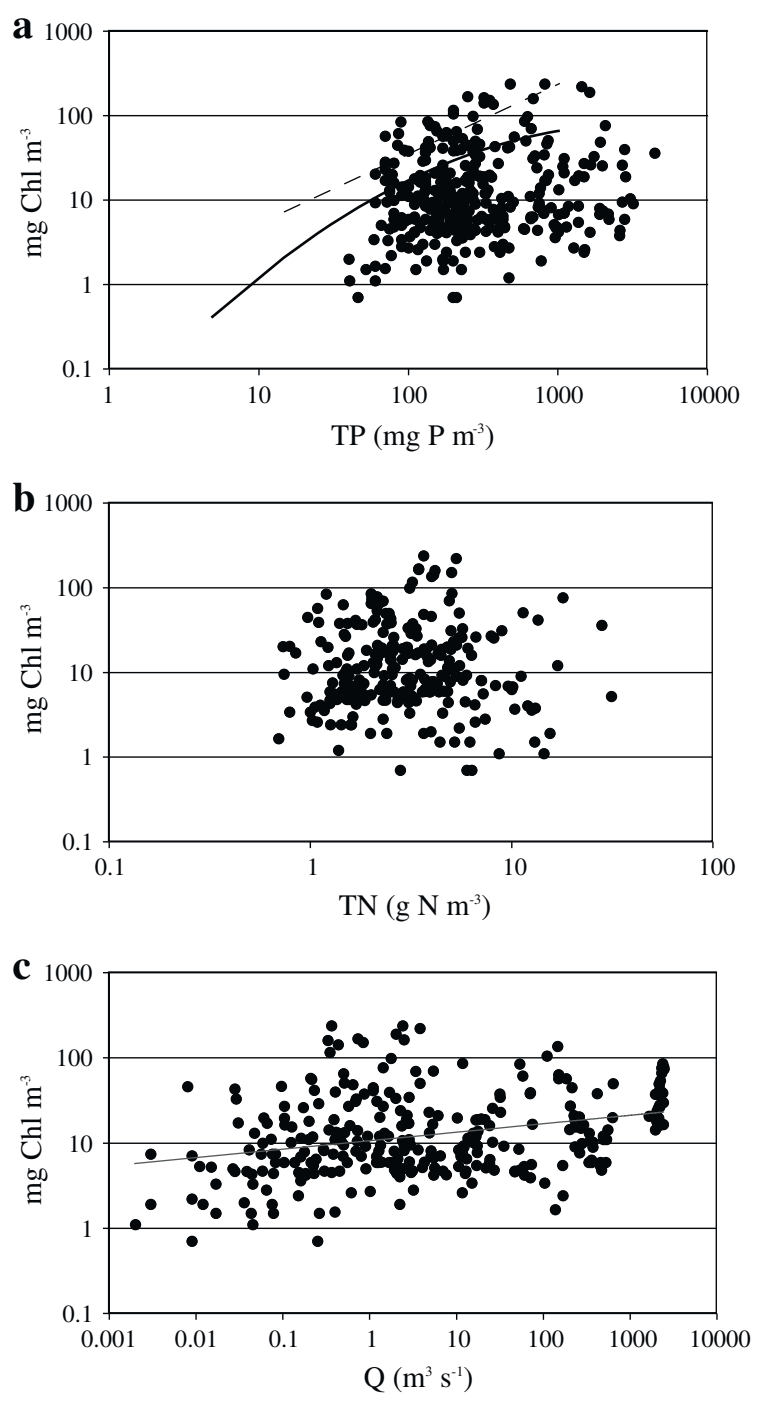

Fig. 2 Decadal median $\mathrm{Chl}$ as a function of nutrient concentrations (TP, TN) and discharge $(Q)$. a Thick line and dotted line represent the river model of van Nieuwenhuyse \& Jones (1996) and the lake model of Jackson et al. (2007), respectively, in the range of TP in those studies. c Thin line is the regression line fitted to the data; $r=0.32, n=290, P<0.001$

and $0.4 \mu \mathrm{g} \mathrm{Chl}[\mu \mathrm{g} \mathrm{P}]^{-1}$ ). The respective values were tenfold lower for DIN. Both P- and N-specific yields tended to increase nonlinearly with $L$ (Fig. $3 \mathrm{c}, \mathrm{d}$ ). Several small HP streams, in which the $L$ versus $\mathrm{Chl}$ relationship was statistically indistinguishable from that at the N-MP sites, showed lower P-specific Chl yield than N-MP streams of comparable sizes (Fig. 3). A similar pattern could not be observed in the N-specific Chl yield. 
Table 3 Comparison of natural-moderately polluted (N-MP) and highly polluted (HP) sites distinguished by using cut-off values of selected variables

\begin{tabular}{|c|c|c|c|c|c|c|c|}
\hline \multirow[t]{2}{*}{ Variable } & \multirow[t]{2}{*}{ Cut-off value } & \multicolumn{3}{|c|}{ N-MP sites $(n=56)$} & \multicolumn{3}{|c|}{ HP sites $(n=290)$} \\
\hline & & Median & Min & $\operatorname{Max}$ & Median & Min & Max \\
\hline $\mathrm{pH}$ & - & 8.08 & 7.55 & 8.50 & 8.00 & 7.46 & 8.97 \\
\hline Conductivity $\left(\mu \mathrm{S} \mathrm{cm}^{-1}\right)$ & - & 346 & 233 & 990 & 704 & 207 & 2,900 \\
\hline $\mathrm{Ca}^{2+}\left(\mathrm{g} \mathrm{m}^{-3}\right)$ & - & 48 & 30 & 123 & 78 & 25 & 228 \\
\hline $\mathrm{Mg}^{2+}\left(\mathrm{g} \mathrm{m}^{-3}\right)$ & - & 12 & 4 & 75 & 29 & 5 & 161 \\
\hline $\mathrm{K}^{+}\left(\mathrm{g} \mathrm{m}^{-3}\right)$ & - & 3 & 2 & 16 & 6 & 2 & 45 \\
\hline $\mathrm{Na}^{+}\left(\mathrm{g} \mathrm{m}^{-3}\right)$ & - & 11 & 5 & 42 & 33 & 8 & 585 \\
\hline $\mathrm{Cl}^{-}\left(\mathrm{g} \mathrm{m}^{-3}\right)$ & $\geq 35$ & 17 & 7 & 33 & 38 & 7 & 390 \\
\hline $\mathrm{HCO}_{3}{ }^{-}\left(\mathrm{g} \mathrm{m}^{-3}\right)$ & - & 165 & 85 & 525 & 348 & 92 & 1,019 \\
\hline $\mathrm{SO}_{4}{ }^{2-}\left(\mathrm{g} \mathrm{m}^{-3}\right)$ & - & 37 & 13 & 189 & 76 & 14 & 912 \\
\hline Suspended solids $\left(\mathrm{g} \mathrm{m}^{-3}\right)$ & - & 22 & 4 & 49 & 28 & 4 & 130 \\
\hline $\mathrm{NH}_{4}-\mathrm{N}\left(\mathrm{mg} \mathrm{N} \mathrm{m}^{-3}\right)$ & - & 45 & 20 & 230 & 130 & 30 & 21,830 \\
\hline $\mathrm{NO}_{2}-\mathrm{N}\left(\mathrm{mg} \mathrm{N} \mathrm{m}^{-3}\right)$ & - & 15 & 3 & 61 & 40 & 5 & 1,777 \\
\hline $\mathrm{NO}_{3}-\mathrm{N}\left(\mathrm{mg} \mathrm{N} \mathrm{m}^{-3}\right)$ & - & 1,225 & 350 & 12,090 & 1,580 & 60 & 28,700 \\
\hline $\mathrm{TN}\left(\mathrm{mg} \mathrm{N} \mathrm{m}^{-3}\right)$ & - & 1,800 & 695 & 14,500 & 3,115 & 845 & 31,300 \\
\hline $\operatorname{SRP}\left(\mathrm{mg} \mathrm{P} \mathrm{m}^{-3}\right)$ & - & 34 & 9 & 86 & 137 & 10 & 4,205 \\
\hline $\mathrm{TP}\left(\mathrm{mg} \mathrm{P} \mathrm{m}^{-3}\right)$ & $\geq 150$ & 96 & 40 & 148 & 270 & 52 & 4,450 \\
\hline DIN:SRP (mg N [mg P] $]^{-1}$ ) & - & 37 & 9 & 1,311 & 13 & 0.2 & 551 \\
\hline $\mathrm{O}_{2}$ saturation $(\%)$ & - & 94 & 61 & 128 & 83 & 17 & 143 \\
\hline $\mathrm{BOD}_{5}\left(\mathrm{~g} \mathrm{O}_{2} \mathrm{~m}^{-3}\right)$ & - & 2.2 & 0.8 & 4.2 & 3.6 & 0.9 & 11.5 \\
\hline $\operatorname{COD}\left(\mathrm{g} \mathrm{O}_{2} \mathrm{~m}^{-3}\right)$ & $\geq 20$ & 11 & 3 & 20 & 21 & 6 & 126 \\
\hline Chl $\left(\mathrm{mg} \mathrm{m}^{-3}\right)$ & - & 5.9 & 0.7 & 49.5 & 9.8 & 0.7 & 237 \\
\hline$L(\mathrm{~km})$ & - & 311 & 3.5 & 1,417 & 48 & 1.2 & 1,417 \\
\hline
\end{tabular}

Bold-significant $(P<0.001)$ difference between the N-MP and HP sites

Chlorophyll-nutrient relationships

within individual sites

Due to the low number of data points (8-30), the correlation between $\mathrm{Chl}$ and nutrients or $Q$ was rarely highly significant within individual sites (Fig. 4). Using $P<0.1$ as significant, $\mathrm{Chl}$ was still independent of any of the examined variables at $28 \%$ of sites. $Q$ alone $(17 \%)$ or in combination with one or both nutrients $(33 \%)$ explained a part of the variability in $\mathrm{Chl}$ at half of the sites. Chl was more often related to $\mathrm{P}$ than to $\mathrm{N}$ (43 and $32 \%$ of sites, respectively).

The effect of reduced nutrient emissions

There was a distinct long-term trend in the concentration of dissolved nutrients at sites where time series were available for three decades (Fig. 5). The prevailing pattern was a considerable decrease in the concentration of nutrients during the early 1990s, usually followed by a leveling off during the late 1990s. The diminishing proportion of ammonium and nitrite in DIN suggested that improved sewage treatment contributed the most to the reduction of nutrient loads.

In the Danube $(L=1,083 \mathrm{~km})$, the significant decrease in SRP was paralleled by a similar trend in $\mathrm{Chl}$ at a more-or-less constant level of DIN (Fig. 5). In the Körös River $(L=374 \mathrm{~km})$, a significant reduction occurred in DIN but not in SRP or Chl. In the Tisza and Maros Rivers ( $L=746$ and $744 \mathrm{~km}$, respectively), concentration of both nutrients decreased significantly from the early 1990s without a concomitant trend in Chl. In the Maros River, flow variability accounted for most of the hectic year-to-year variability in algal biomass (for the $\log (\mathrm{Chl})=f(Q)$ regression $\left.r^{2}=0.84, n=24, P<0.001\right)$. In the Zala River $(L=85 \mathrm{~km})$, a significant trend was observed in both 

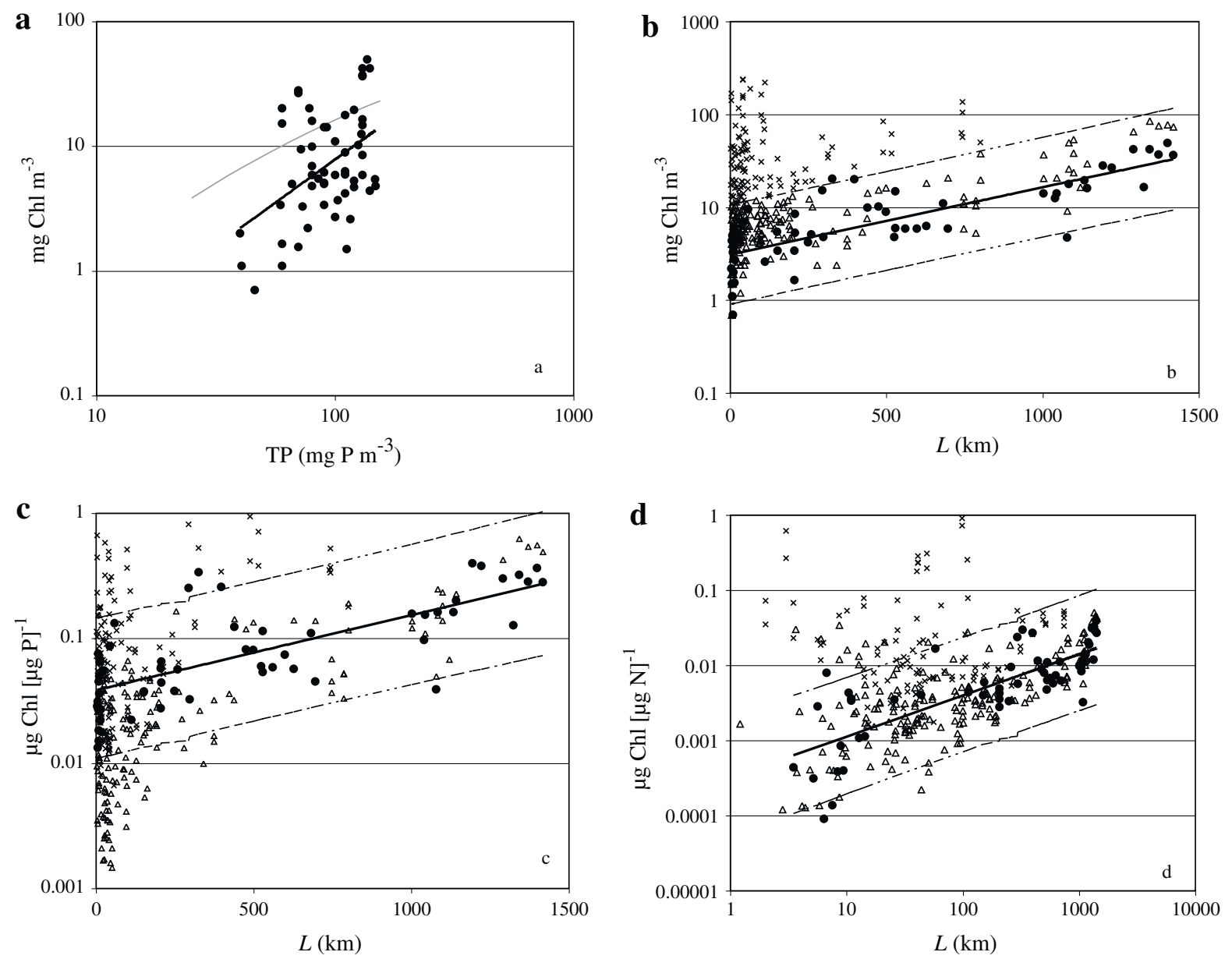

Fig. 3 Decadal median Chl as a function of TP (a) and upstream length $-L(\mathbf{b})$ and nutrient-specific $\mathrm{Chl}$ yield $(\mathbf{c}, \mathbf{d})$. a Thin and thick lines represent the model of van Nieuwenhuyse \& Jones (1996) and the regression line fitted to the data $(r=0.45$, $n=56, \quad P<0.001)$, respectively. b-d Dashed line 95\% confidence limit, closed circle natural-moderately polluted (N-MP) sites, open diamond highly polluted (HP) sites within

nutrients before stabilizing at high levels (mean concentration of DIN was $1,802 \pm 102 \mathrm{mg} \mathrm{N} \mathrm{m}^{-3}$ after 1995; that of SRP was $137 \pm 39 \mathrm{mg} \mathrm{P} \mathrm{m}^{-3}$ after 1999). In spite of this, Chl has decreased significantly from 1989.

At $40 \%$ of the 184 sites where trend analysis could be performed, a significant linear trend was observed in Chl (Fig. 6). The general trend was a decrease at an average rate of 2 and a maximum rate of $12 \mathrm{mg} \mathrm{Chl} \mathrm{m}^{-3}$ year $^{-1}$. In about $75 \%$ of cases when Chl decreased, so did one or both of the nutrients. The rate of decrease in nutrients averaged at $26 \mathrm{mg} \mathrm{P} \mathrm{m}^{-3}$ year $^{-1}$ and $172 \mathrm{mg} \mathrm{N} \mathrm{m}^{-3}$ year $^{-1}$. Maxima exceeded $200 \mathrm{mg} \mathrm{P} \mathrm{m}^{-3}$ year $^{-1}$ and

the $95 \%$ confidence interval in Fig. 3b, cross HP sites beyond the 95\% confidence interval in Fig. 3b. Parameters of the regression lines fitted to the data of the N-MP sites are as follows: $\ln (\mathrm{Chl})=1.13 \pm 0.12+0.0017 \pm 0.0002 L, r^{2}=0.64 ; \ln (\mathrm{Chl}$ $\left.[\mathrm{TP}]^{-1}\right)=-3.26 \pm 0.12+0.0014 \pm 0.0002 L, r^{2}=0.54 ; \log$ $\left(\mathrm{Chl}[\mathrm{DIN}]^{-1}\right)=-8.05 \pm 0.32+0.55 \pm 0.06 \log (L), r^{2}=0.62$. For each regression, $n=56, P<0.001$

$1,000 \mathrm{mg} \mathrm{N} \mathrm{m}^{-3}$ year $^{-1}$. In most cases, however, reduced nutrient concentrations remained much too high to substantiate the trend in Chl. Moreover, there were 18 sites where $\mathrm{Chl}$ decreased in spite of the unchanged or even increasing nutrient concentrations. Finally, the downward or upward trend in one or both nutrients failed to provoke a corresponding trend in Chl at 69 sites.

We estimated the apparent efficiency of emission control by dividing the long-term change in Chl with that in nutrients. Nutrient reduction was marginally efficient $\left(<0.1 \mu \mathrm{g} \mathrm{Chl}[\mu \mathrm{g} \mathrm{P}]^{-1}\right.$ and $<0.03 \mu \mathrm{g} \mathrm{Chl}$ $[\mu \mathrm{g} \mathrm{N}]^{-1}$ ) below a threshold length of about $150 \mathrm{~km}$ (Fig. 7). The efficiency steeply increased in larger 


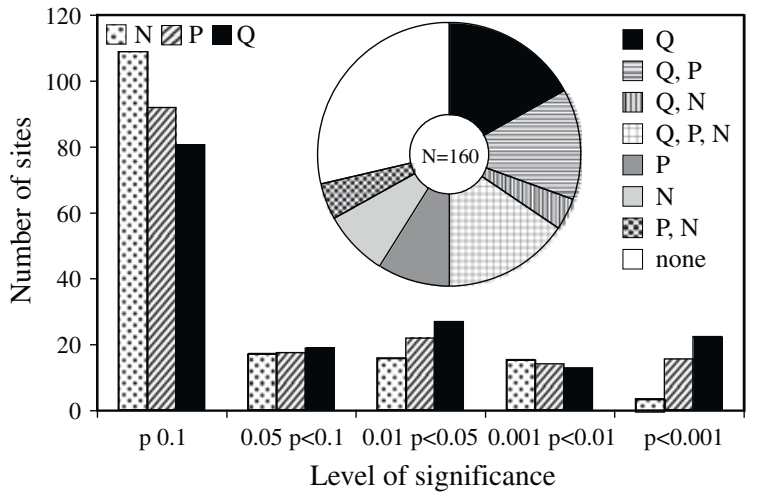

Fig. 4 Distribution of sites based on the significance level $(P)$ of the best fitting simple regression model describing the dependence of yearly median Chl on nutrients (TP, DIN) and discharge $(Q)$ at individual sites. Insertion shows sites at which Chl showed significant $(P<0.1)$ correlation with none, one, or more of the independent variables
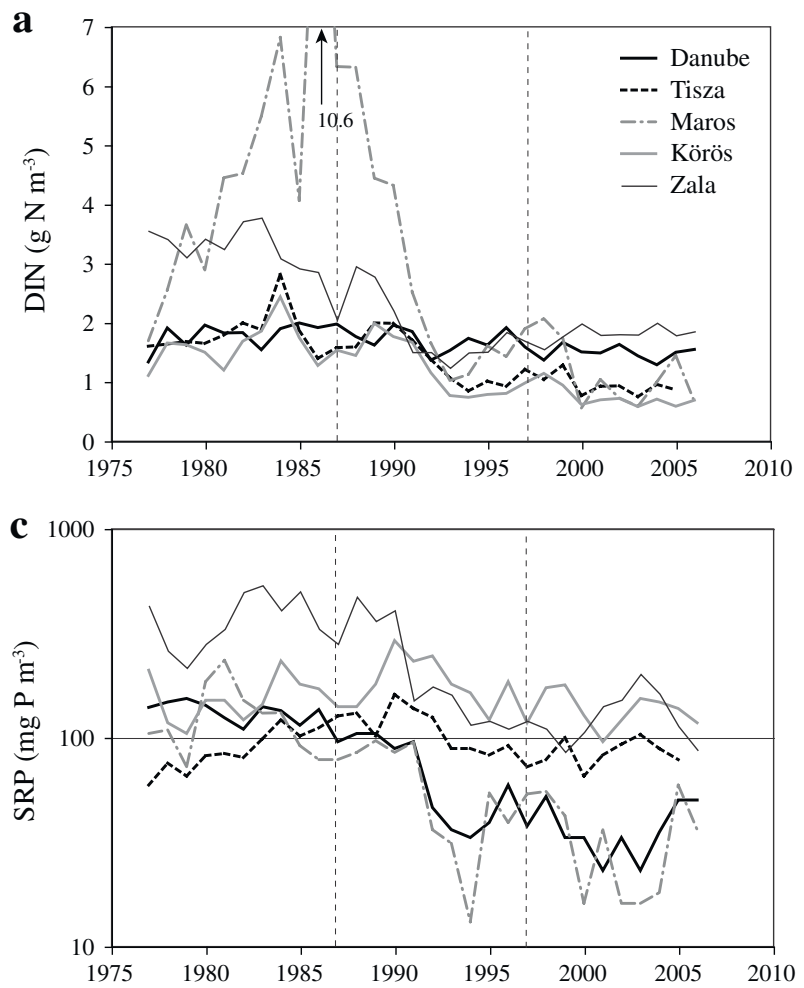

Fig. 5 Annual median concentration of nutrients, Chl and percentage contribution of ammonium plus nitrite (non-nitrate $\mathrm{N})$ to DIN in five rivers. Long-term monitoring sites are shown in Fig. 1. Vertical lines indicate the three periods used to calculate decadal median data. Determination coefficient of significant $(P<0.001)$ linear trends were as follows: Danube, rivers. The highest efficiency (about $1.5 \mu \mathrm{g}$ Chl $[\mu \mathrm{g}$ $\mathrm{P}]^{-1}$ and $0.15 \mu \mathrm{g} \mathrm{Chl}[\mu \mathrm{g} \mathrm{N}]^{-1}$ ) was observed in the Danube downstream of $L=1,300 \mathrm{~km}$. Pooling yearround data from the five sites along this reach, the SRP concentration was less than $10 \mathrm{mg} \mathrm{P} \mathrm{m}^{-3}$ in $0.1 \%$ of samples in 1987-1991 $(n=930)$. A nearly linear frequency increase occurred in the subsequent 5 -year periods up to $25 \%$ in $2002-2006(n=746)$.

\section{Discussion}

Determinants of sestonic Chl

Our study covered a wide range of stream hydrogeomorphic types and sizes (Table 1). As a consequence, sestonic Chl represented algae that were recruited
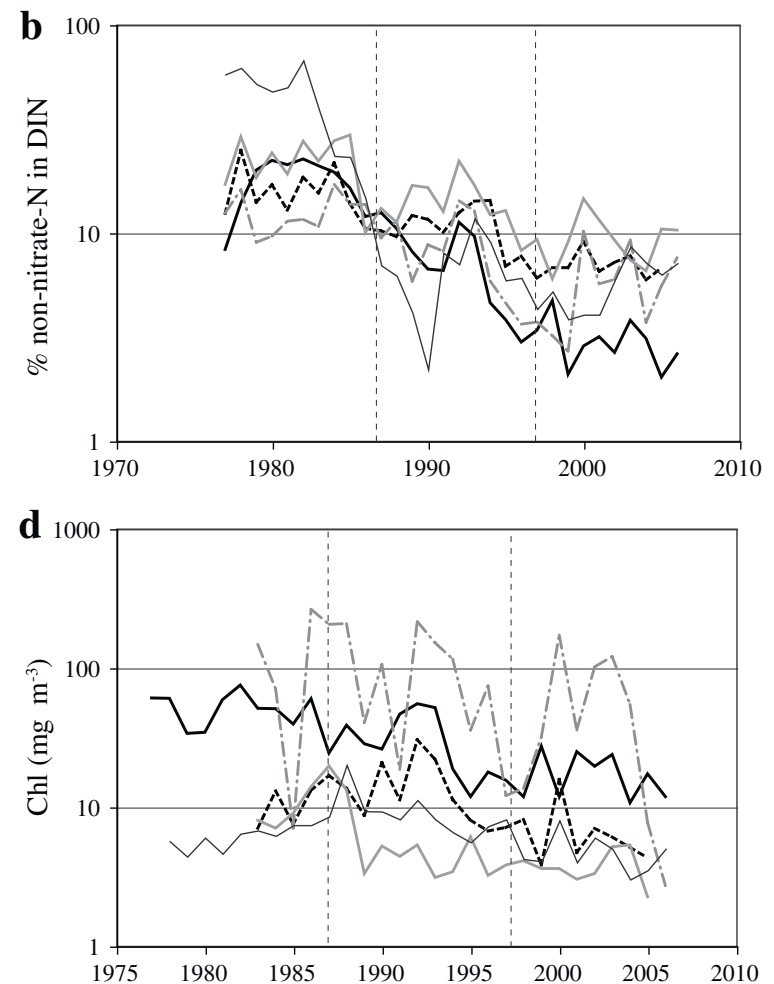

SRP: $r^{2}=0.83$, Chl $: r^{2}=0.57, n=30$. Tisza, SRP: $r^{2}=0.33$, DIN $: r^{2}=0.65, \quad n=23 . \quad$ Maros, $\quad$ SRP $: r^{2}=0.63$, DIN $: r^{2}=0.63, n=24$. Körös, DIN: $r^{2}=0.72, n=25$. Zala, SRP: $r^{2}=0.82, \quad n=18 ; \quad$ DIN: $r^{2}=0.85, \quad n=14$; Chl: $r^{2}=0.62, n=20$ 


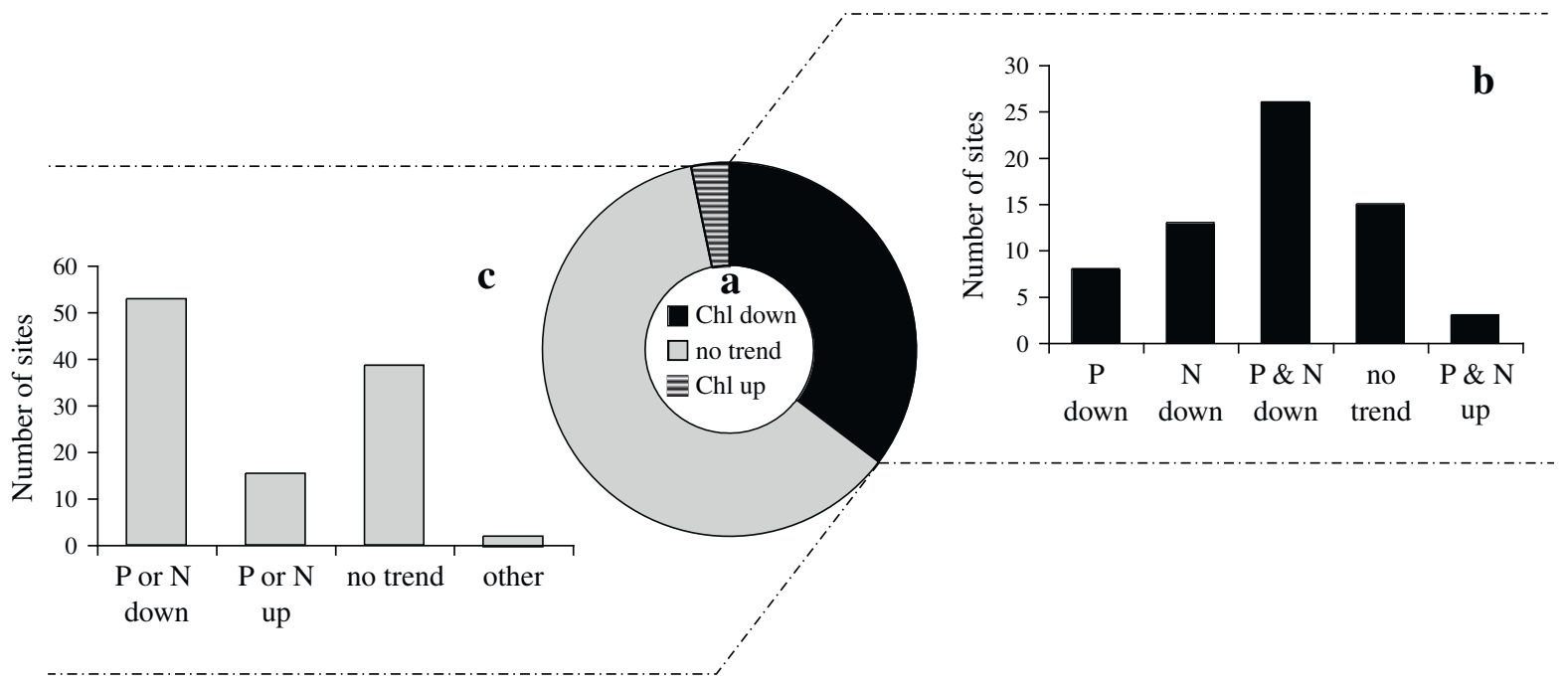

Fig. 6 Summary of long-term $(>8$ years) significant $(P<0.05)$ linear trends in summer median $\mathrm{Chl}(\mathbf{a})$ and nutrients $(\mathbf{b}, \mathbf{c})$ within individual sites. The total number of sites was 184
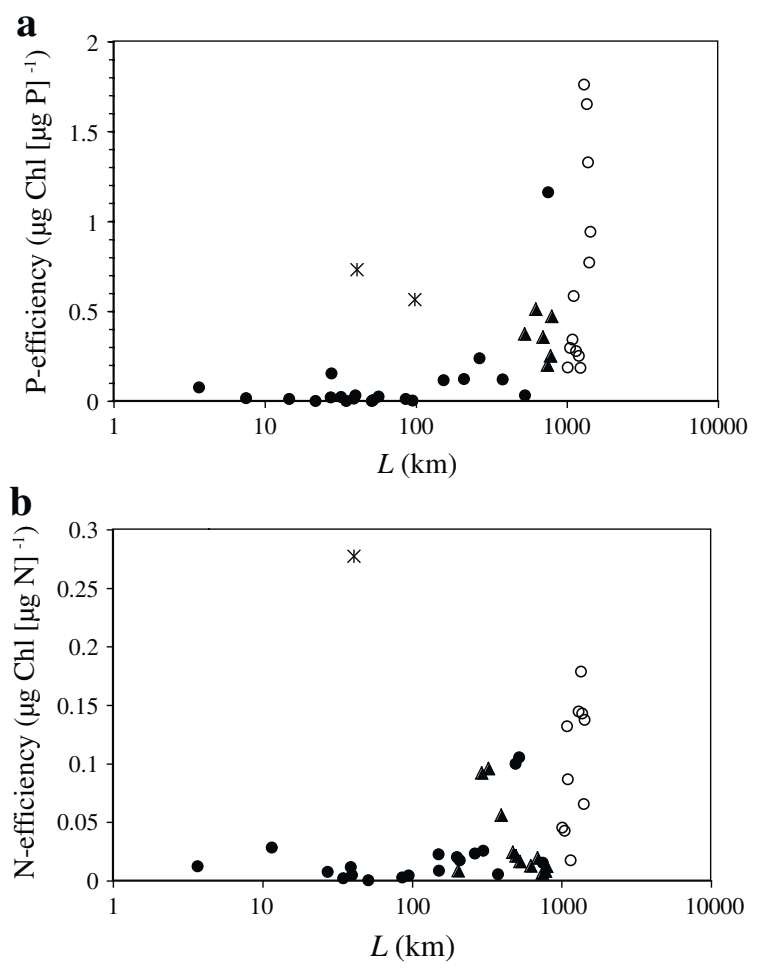

Fig. 7 Apparent efficiency of nutrient management in reducing median Chl. P- and N-efficiency was the quotient of the slopes of parallel linear trends in $\mathrm{Chl}$ and the respective nutrient. Open symbol Danube, closed triangle Tisza River, cross outflow of large, hypertrophic reservoirs from diverse sources. In headwater streams without reservoirs, Chl might primarily be associated with benthic algae, which are continuously resuspended in proportion to the surface area of the upstream streambed during low flow (Swanson \& Bachmann, 1976). While true potamophytoplankton dominate in many rivers of 3rd order or higher, a system-specific fraction of $\mathrm{Chl}$ is associated with fluvial, limnetic, benthic, epiphytic, and meroplanktonic species (Uherkovich, 1971; Reynolds \& Descy, 1996; Istvánovics \& Honti, 2011). In the present study we could not directly account for periphyton due to the lack of data. It is indeed a major deficiency shared by other studies based on routine monitoring data (Søballe \& Kimmel, 1987; Van Nieuwenhuyse \& Jones, 1996; Royer et al., 2008). Thus, we could only rely on the indirect evidence of benthic algal biomass that appears via its influence on sestonic Chl.

The majority of our sites were obviously affected by sewage. TP and $\mathrm{N}$ forms abundant in sewage effluents (ammonium and nitrite) showed a positive correlation with other sewage-related components $\left(\mathrm{Na}^{+}, \mathrm{Cl}^{-}\right.$, COD) in the whole data set (Table 2). This pattern was consistent with the relatively modest contribution of agriculture to nutrient emissions in the CEE countries. Prior to the 1990s, the relatively small contribution of agricultural load was primarily due to the large portion of sewage (60-70\%), which was 
emitted into the rivers without any treatment (Somlyódy \& Shanahan, 1998). Although nutrient emission has rapidly decreased with improved sewage treatment and the collapse of industry from the early 1990s, the parallel collapse of agriculture kept the share of diffuse nutrient loads at low level. The present contribution of agriculture to $\mathrm{P}$ emission was estimated as $10 \%$ (Csathó et al., 2007). Unlike in the developed countries (Neal et al., 2008), 50-60\% of $\mathrm{N}$ emission also originated from point sources in the CEE countries in 2000 (Schreiber et al., 2005) and accordingly, the 90th percentiles of decadal median nutrient concentrations were as high as $690 \mathrm{mg} \mathrm{N} \mathrm{m}^{-3}$ ammonium, $5.7 \mathrm{~g}$ $\mathrm{N} \mathrm{m}^{-3}$ DIN, $820 \mathrm{mg} \mathrm{P} \mathrm{m}^{-3} \mathrm{SRP}$, and $1,100 \mathrm{mg}$ $\mathrm{P} \mathrm{m}^{-3}$ TP. The most nutrient-rich systems were streams of 10-100 km length (Table 3), which receive sewage discharge well in excess of their dilution capacity. At the same time, median concentration of DIN was low (1.8 $\mathrm{g} \mathrm{N} \mathrm{m}^{-3}$; Table 1$)$ relative to that found in rivers of intensely cultivated areas. For example, nitrate averaged at $1.9 \mathrm{~g} \mathrm{~N} \mathrm{~m}^{-3}$ in rivers of low intensity agricultural catchments in the Northeastern UK and exceeded $10 \mathrm{~g} \mathrm{~N} \mathrm{~m}^{-3}$ in agricultural rivers of East Anglia (Robson \& Neal, 1997).

The lowest median TP concentration was an order of magnitude higher than in the North-American rivers, where significant correlation was found between TP and Chl (Table 3; Fig. 3; Basu \& Pick, 1996; van Nieuwenhuyse \& Jones, 1996; Chételat et al., 2006). This was partly due to the high geochemical background of $\mathrm{P}$ in the Carpathian Basin (Ódor et al., 1997; Salminen et al., 2005). High nutrient concentratons, however, supported conspicuously lower levels of $\mathrm{Chl}$ at the majority of our sites compared to other studies (Figs. 2, 3). According to the nutrient criteria of Dodds \& Welch (2000), sestonic Chl below $8 \mathrm{mg} \mathrm{m}^{-3}$ can be expected when $\mathrm{TP}<42 \mathrm{mg} \mathrm{P} \mathrm{m}^{-3}$ and $\mathrm{TN}<290 \mathrm{mg} \mathrm{N} \mathrm{m}^{-3}$. In our data set, decadal median Chl was $<8 \mathrm{mg} \mathrm{m}^{-3}$ at 157 sites, while the proposed nutrient criteria were met only at 2 of these sites. In turn, at sites with $<8 \mathrm{mg} \mathrm{Chl}$ $\mathrm{m}^{-3}$ both TP and DIN exceeded the criteria by a mean factor of 10 .

The time constraint imposed by short WRT upon growth might limit Chl to generally low levels in the examined streams and rivers. Yearly median Chl concentration was more frequently and more significantly related to $Q$ than to nutrients (Fig. 4). At the reference sites, as well as at the majority of polluted sites, Chl increased with upstream length (Fig. 3) and median $Q$ over a 10 -year period (not shown). Since $L$ and $Q$ are the two closely related parameters, from which a rough estimate of WRT can be derived in running waters (Søballe \& Kimmel, 1987; Walks, 2007), the dependence of $\mathrm{Chl}$ on $L$ and $Q$ reflects the impact of WRT. Similar to our results, a positive relationship was found between WRT and algal cell abundance in a large set $(n=345)$ of streams in the USA (Søballe \& Kimmel, 1987). The relationship between the characteristic, long-term WRT and Chl does not imply that the instantaneous Chl concentration or algal biovolume could be predicted from a rough ( $L$ - and $Q$-based) estimate of WRT (Basu \& Pick, 1996; Chételat et al., 2006), because this estimate does not account for the spatial heterogeneity of flow, which is a physical prerequisite for algal growth in rivers (Reynolds, 2000; Walks, 2007; Istvánovics \& Honti, 2011).

Median WRT ranged from $4 \mathrm{~h}$ in the smallest streams to nearly 3 weeks in the downstream reach of the Danube. WRT was sufficiently long in the latter river to result in frequent $\mathrm{P}$ limitation of phytoplankton growth and in a P-specific Chl yield (0.28-0.38 $\mu \mathrm{g} \mathrm{Chl}$ $[\mu \mathrm{g} \mathrm{P}]^{-1}$ ) that closely matched the prediction of van Nieuwenhuyse \& Jones (1996). Accordingly, P reduction led to a significant improvement in the trophic status of the Danube (Figs. 5, 7). In contrast, WRT was too short $(<2-3$ days) to exploit the available $\mathrm{P}$ in many smaller $(<150 \mathrm{~km})$ rivers, and thus, excess $\mathrm{P}$ in $\mathrm{HP}$ rivers resulted in significantly lower $\mathrm{P}$-specific $\mathrm{Chl}$ yield than at the N-MP sites (Fig. 3). The apparent efficiency of nutrient management was marginal in these systems (Fig. 7). Unlike P-specific Chl yield, the $\mathrm{N}$-specific yield was similar in low order HP streams to that at the N-MP sites (Fig. 3). This was presumably due to a combination of intense denitrification and $\mathrm{N}$ assimilation by benthic algae, the growth of which may often be N-limited (Francoeur, 2001).

Chl exceeded the upper $95 \%$ confidence interval of the $L$ versus $\mathrm{Chl}$ regression at $50 \mathrm{HP}$ sites (Fig. 3). At most of these sites, both $\mathrm{P}$ - and $\mathrm{N}$-specific Chl yield was high relative to $L$ (and WRT). This might reflect the impact of various impoundments (reservoirs, fishponds, shallow lakes), which are common in Hungary. These impoundments significantly elongate WRT, enhance the exploitation of nutrients, and when eutrophic, inoculate the downstream sections of the river network with substantial amounts of algae 
(Billen et al., 2007; Honti et al., 2010). Although limnetic species are likely to be lost during the downstream travel (Reynolds \& Descy, 1996), the decrease in sestonic Chl will be small at short WRT.

The different approaches used in this study suggested that nutrients had usually a minor influence on Chl. Decadal median Chl was unrelated to $\mathrm{P}$ or $\mathrm{N}$ in the whole data set (Table 2; Fig. 2), and weakly related to TP at the N-MP sites (Fig. 3). Yearly median Chl was not significantly $(P<0.1)$ related to nutrients at half of the sites (Fig. 4). A long-term downward trend could be observed in both $\mathrm{Chl}$ and nutrients at many sites (Figs. 5, 6). However, combinations that might suggest a direct linkage (similar trend or no trend in Chl and nutrients) did not occur more frequently than combinations suggesting independence (Fig. 6).

No information was available to assess the impact of other, potentially important determinants of sestonic Chl, like light availability, flow variability, or grazing. Using yearly or decadal median data, light conditions might contribute the most to the unaccounted variability in Chl. Light limitation was shown to prevail even during low flow in several medium- to large-sized rivers of this study (Uherkovich, 1971; Dokulil, 2006; Istvánovics et al., 2010; Istvánovics \& Honti, 2011). Shading by aquatic and riparian macrovegetation might be important in low gradient smallto medium-sized rivers and in headwater streams of forested catchments, respectively.

\section{Apparent efficiency of nutrient management}

Long-term trends in nutrients reflected the trends in nutrient emissions (Schreiber et al., 2005; Csathó et al., 2007) in rivers where data were available for three decades (Fig. 5). The Danube was the single one among these rivers where reduced $\mathrm{P}$ load resulted in a substantial drop in algal biomass (Fig. 5) and a concomitant increase in species diversity of phytoplankton (Verasztó et al., 2010). Simultaneously, this was one of the rivers where the frequency of potentially growth-limiting SRP concentrations $(<10 \mathrm{mg}$ $\mathrm{P} \mathrm{m}^{-3}$ ) increased during the management and reached 25\% in 2002-2006. Most probably, P limitation along the lower section of the Hungarian Danube was not independent of the impact of over 700 dams and impoundments built in the upstream catchment (ICPDR, 2005). Besides elongating WRT and thereby potentially enhancing algal growth, these reservoirs retain suspended matter that results in a significant improvement in the light conditions along the Middle Danube (Kiss, 1994; Vörös et al., 2000).

Nutrient concentrations showed a significant $(P<0.05)$ linear downward trend at about half of our sites. With a nearly equal frequency, a parallel trend might or might not occur in Chl (Figs. 5, 6). Apparent efficiency of emission control was low in smalland medium-sized systems $(L<150 \mathrm{~km}$; median WRT $<2-3$ days) with the exception of two sites immediately downstream of hypertrophic reservoirs (WRT > 2-3 weeks; Fig. 7). Above an upstream length of about $150 \mathrm{~km}$, apparent efficiency steeply increased with $L$ (and WRT) to achieve values along the lower section of the Hungarian Danube, which were comparable to those observed in shallow lakes recovering from eutrophication (Sas, 1989). The strong dependency of apparent management efficiency on $L$ implies that no universal nutrient criteria can be applied to achieve target levels of suspended $\mathrm{Chl}$ in individual streams and rivers effectively. Since rivers differ in their response to nutrient loads depending on their size and placement within the stream network, eutrophication control must be based on the local circumstances.

\section{Implications for management}

The EU WFD requires improving the ecological status of individual water bodies and pays special attention to nutrient management in river basins. At a basin-wide scale, nutrient criteria should aim at preventing eutrophication in transitional and coastal waters of the Danube River Basin (IPCDR, 2005). Considering the low apparent efficiency of nutrient management in most rivers of this study (Fig. 7), the question arises how reasonable nutrient criteria could be applied to improve the trophic status of individual streams and rivers while fulfilling the basin-wide goal of nutrient management. One approach is to apply the same nutrient criteria to each river within an ecoregion (Hansen \& Christ, 2001; Dodds \& Oakes, 2004). Differences in altitude, catchment size, geology, and additional factors were taken into account to derive nutrient criteria for various types of streams and rivers in the Danube Basin countries (IPCDR, 2005). However, the fluvial network is inherently heterogeneous. We propose that nutrient criteria must be tailored to the typical nutrient-Chl response function of the given 

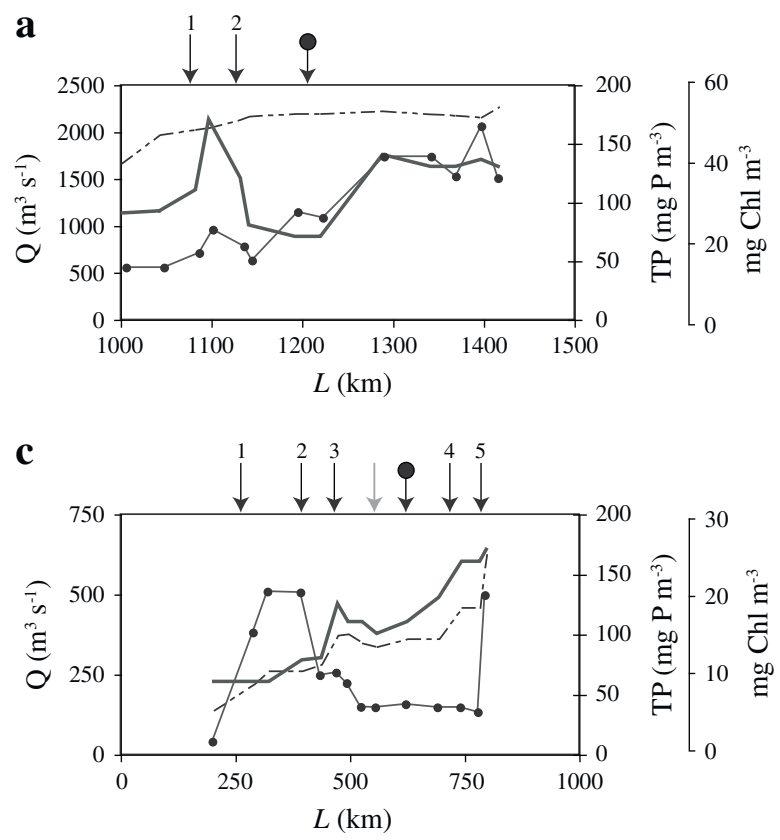

Fig. 8 Longitudinal profiles of median discharge $(Q)$, TP and Chl in the period 1997-2006 in four rivers that exemplify four different Chl response classes. a Danube; b Sajó River, c Tisza River, d Zagyva River; see Fig. 1. Dashed line Q, thick line TP, closed symbol Chl. Arrows with circles indicate major cities

river. Longitudinal patterns in decadal (1997-2006) median data in a few rivers of this study revealed four characteristic classes of trophic response to hydraulic properties and nutrient loads (Fig. 8).

The Danube represented Class 1 response (Fig. 8a). In this large river the median biomass of phytoplankton was P-determined (cf. Figs. 5, 7), and thus, nutrient criteria could be applied to further decrease Chl.

The Sajó (Slaná in Slovakian) River, a highly polluted tributary of the Tisza River (Somlyódy et al., 1999) exemplified Class 2 response (Fig. 8b). $Q$ and $\mathrm{Chl}$ increased relatively smoothly along the flow in spite of elevated nutrient emission from a large industrial town along the riverbank (170,000 inhabitants). Neither tributaries nor reservoirs caused discontinuity in nutrients or Chl that could be detected by the methods of this study. A reasonable nutrient criterion might aim at reducing the longitudinal increase in TP (and DIN, not shown) along the Sajó River to eliminate the elevated nutrient concentrations in the recipient Tisza River (Fig. 8c). However, to reduce local $\mathrm{Chl}$ concentrations one should manage the numerous upstream ponds and reservoirs that may

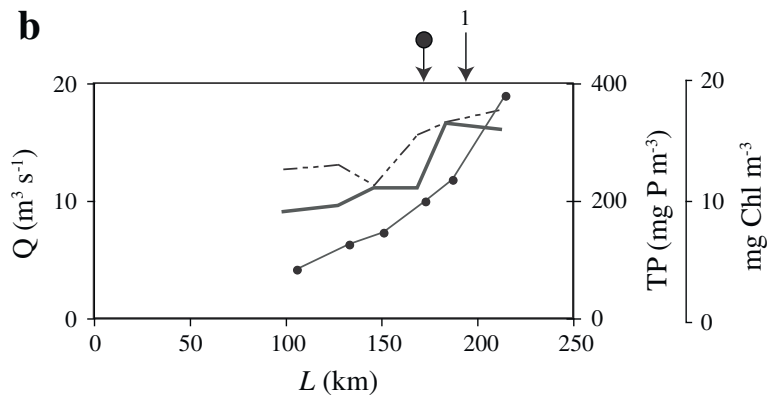

d

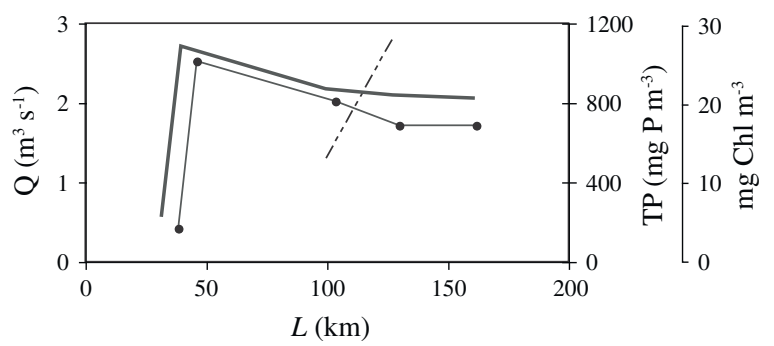

situated on the riverbank. Numbered arrows indicate large tributaries. a 1 Vág (Vah) River, 2 Garam (Hron) River. b 1 Hernád (Hornád) River. c 1 Szamos (Someş) River, 2 Bodrog River, 3 Sajó (Slaná) River, 4 Körös (Criş) River, 5 Maros (Mureş) River, dashed arrow indicates a major dam

leach algae into the river. Class 2 response was characteristic of several medium-sized and large rivers of this study.

The Tisza River, the largest tributary of the Danube represented Class 3 response (Fig. 8c). The highly discontinuous $\mathrm{Chl}$ profile contrasted the relatively smooth downstream increase in $Q$ and TP. Most of the Chl originated from the hypertrophic Szamos (Someş in Romanian) and Maros (Mureş in Romanian) Rivers. Algae exported by the shallow Szamos were lost while advecting along the deep channel of the Tisza River. This loss was further enhanced by the rapid sedimentation of diatoms upstream of a large dam (Fig. 8c; Honti et al., 2008; Istvánovics et al., 2010). Noticeably, the Szamos River was not significantly richer in nutrients than the Upper Tisza River, but its shallow channel favored the growth of meroplanktonic diatoms (Istvánovics \& Honti, 2011). The trophic status of the Tisza River depended primarily on the status of its large, shallow tributaries (the Szamos and the Maros Rivers), so water quality management should focus on these rivers to decrease $\mathrm{Chl}$ in the main channel. 
An example of Class 4 response is the small domestic Zagyva River (Fig. 8d), another tributary of the Tisza. The concentration of nutrients was extremely high. Chl was also high relative to $L$, and peaked together with the nutrients at such a short $L$ as $40 \mathrm{~km}$. The atypical Chl profile was due to the algal export from the many hypertrophic fishponds and reservoirs in the catchment (Erös et al., 2011). Class 4 response might be characteristic in most of the polluted low order rivers, in which $\mathrm{Chl}$ exceeded the upper $95 \%$ confidence limit of the $L$ versus Chl regression obtained at the N-MP sites (Fig. 3), and the productivity of which was higher than in shallow Danish lakes (Fig. 2). In these systems nutrient criteria must primarily be applied to the impoundments (Honti et al., 2010). Supervising the operation of ponds and reservoirs should be a focal point in managing the trophic status along the downstream fluvial network.

The four observed response classes mainly correspond to the topological position of a given river in the entire river network. Classes 1 and 3 were typical for high order rivers. Classes 2 and 4 contained small- and medium-sized streams and rivers. A response-based management of the trophic status of individual rivers requires modeling algal growth at the network scale. Further studies are needed, since at present, only a few models capture processes at the relevant spatial scale (Billen et al., 1994, 2007; Honti et al., 2010).

Acknowledgments This study was financially supported by the National Science Foundation (OTKA) Grant No. 63340. We are grateful to Dr. Adrienne Clement for providing the data and the maps to construct Fig. 1. Two anonymous referees helped us to improve a previous version of this paper.

\section{References}

Basu, B. K. \& F. R. Pick, 1996. Factors regulating phytoplankton and zooplankton biomass in temperate rivers. Limnology and Oceanography 41: 1572-1577.

Biggs, B. J. F., 2000. Eutrophication of streams and rivers: dissolved nutrient-chlorophyll relationships for benthic algae. Journal of North American Benthological Society 19: 17-31.

Billen, G., J. Garnier \& P. Hanset, 1994. Modelling phytoplankton development in whole drainage networks: the RIVERSTRAHLER model applied to the Seine river system. Hydrobiologia 289: 119-137.

Billen, G., J. Garnier, J. Némery, M. Sebilo, A. Sferratore, S. Barles, P. Benoit \& M. Benôtt, 2007. A long-term view of nutrient transfers through the Seine river continuum. Science of the Total Environment 375: 80-97.
Catt, J. A., 2001. The agricultural importance of loess. EarthScience Reviews 54: 213-229.

Chételat, J., F. R. Pick \& P. B. Hamilton, 2006. Potamoplankton size structure and taxonomic composition: influence of river size and nutrient concentrations. Limnology and Oceanography 51: 681-689.

Csathó, P. \& L. Radimszky, 2011. Towards sustainable agricultural NP turnover in the EU 27 countries: a review. In Tóth, G. \& T. Németh (eds), Land Quality and Land Use Information in the European Union. JRC-IES, Ispra: $69-86$.

Csathó, P., I. Sisák, L. Radimszky, S. Lushaj, H. Spiegel, M. T. Nikolova, N. Nikolov, P. Čermák, J. Klir, A. Astover, A. Karklins, S. Lazauskas, J. Kopiński, C. Hera, E. Dumitru, M. Manojlovic, D. Bogdanović, S. Torma, M. Leskošek \& A. Khristenko, 2007. Agriculture as a source of phosphorus causing eutrophication in Central and Eastern Europe. Soil Use and Management Supplement 23: 36-56.

Dodds, W. K., 2006. Eutrophication and trophic state in rivers and streams. Limnology and Oceanography 51: 671-680.

Dodds, W. K. \& R. M. Oakes, 2004. A technique for establishing reference nutrient concentrations across watersheds affected by humans. Limnology and Oceanography: Methods 2: 333-341.

Dodds, W. K. \& E. B. Welch, 2000. Establishing nutrient criteria in streams. Journal of North American Benthological Society 19: 186-196.

Dokulil, M. 2006. Assessment of potamoplankton and primary productivity in the river Danube: A review. In Proceedings 36th International Conference of IAD. Austrian Committee Danube Research/IAD, Vienna. ISBN 13: 978-3-95007232-7, 1-5.

Erős, T., D. Schmera \& R. S. Shick, 2011. Network thinking in riverscape conservation - a graph-based approach. Biological Conservation 144: 181-192.

Francoeur, S. N., 2001. Meta-analysis of lotic nutrient amendment experiments: detecting and quantifying subtle responses. Journal of North American Benthological Society 20: 358-368.

Froelich, P. N., 1988. Kinetic control of dissolved phosphate in natural rivers and estuaries: a primer on the phosphate buffer mechanism. Limnology and Oceanography 33: 649-668.

Hansen, E. \& M. Christ, 2001. EPA's Nutrient Criteria Recommendations and Their Application in Nutrient Ecoregion XI. http://www.wvrivers.org/wvrcpermitassistance/WVRCPer mitAnalysisProgram_files/NutrientCommentsEcoregionXI. pdf

Hein, T., C. Baranyi, G. J. Herndl, W. Wanek \& F. Schiemer, 2003. Allochthonous and autochthonous particulate organic matter in floodplains of the River Danube: the importance of hydrological connectivity. Freshwater Biology 48: 220-232.

Honti, M., V. Istvánovics \& Z. Kozma, 2008. Assessing phytoplankton growth in River Tisza (Hungary). Verhandlungen der internationle Vereinigung für throretische und angewandte Limnologie 30: 87-89.

Honti, M., V. Istvánovics \& Á. Kovács, 2010. Balancing between retention and flushing in river networks - optimizing nutrient management to improve trophic state. Science of the Total Environment 408: 4712-4721. 
ICPDR, 2005. The Danube River Basin District. Part A—basinwide overview. http://www.icpdr.org/icpdr-pages/reports. htm

Istvánovics, V. \& M. Honti, 2011. Phytoplankton growth in three rivers: the role of meroplankton and the benthic retention hypothesis. Limnology and Oceanography 56: 1439-1452.

Istvánovics, V., M. Honti, L. Vörös \& Z. Kozma, 2010. Phytoplankton dynamics in relation to connectivity, flow dynamics and resource availability - the case of a large, lowland river, the Hungarian Tisza. Hydrobiologia 637: 121-141

Jackson, L. J., T. L. Lauridsen, M. Søndergaard \& E. Jeppesen, 2007. A comparison of shallow Danish and Canadian lakes and implications of climate change. Freshwater Biology 52: $1782-1792$.

Kiss, K. T., 1994. Trophic level and eutrophication of the River Danube in Hungary. Verhandlungen der internationle Vereinigung für throretische und angewandte Limnologie 25: 1688-1691.

Leopold, L. B., M. G. Wolman \& J. P. Miller, 1964. Fluvial Processes in Geomorphology. WH Freeman and Company, San Francisco.

Meybeck, M., 1982. Carbon, nitrogen, and phosphorus transport by world rivers. American Journal of Science 282: 401-450.

Neal, C., H. Davies \& M. Neal, 2008. Water quality, nutrients and the water framework directive in an agricultural region: the lower Humber Rivers, northern England. Journal of Hydrology 350: 232-245.

Ódor, L., I. Horváth \& U. Fügedi, 1997. Low-density geochemical mapping in Hungary. Journal of Geochemical Exploration 60: 55-66.

Reynolds, C. S., 1992. Eutrophication and the management of planktonic algae: what Vollenweider couldn't tell us. In Sutcliffe, D. W. \& J. G. Jones (eds), Eutrophication: Research and Application to Water Supply. FBA, Ambleside: $4-29$.

Reynolds, C. S., 2000. Hydroecology of river plankton: the role of variability in channel flow. Hydrological Processes 14: 3119-3132.

Reynolds, C. S. \& J.-P. Descy, 1996. The production, biomass, and structure of phytoplankton in large rivers. Archiv für Hydrobiologie, Supplementband Large Rivers 113: 161-187.

Reynolds, C. S., J.-P. Descy \& J. Padisák, 1994. Are phytoplankton dynamics in rivers so different from those in shallow lakes? Hydrobiologia 289: 1-7.

Robson, A. J. \& C. Neal, 1997. A summary of regional water quality for Eastern UK rivers. Science of the Total Environment 194(195): 15-37.

Royer, T. V., M. B. David, L. E. Gentry, C. A. Mitchell, K. M. Starks, T. I. Heatherly \& M. R. Whiles, 2008. Assessment of chlorophyll- $a$ as a criterion for establishing nutrient standards in the streams and rivers of Illinois. Journal of Environmental Quality 37: 437-447.

Sabater, S., J. Artigas, C. Durán, M. Pardos, A. M. Romaní, E. Tornés \& I. Ylla, 2008. Longitudinal development of chlorophyll and phytoplankton assemblages in a regulated large river (the Ebro River). Science of the Total Environment 404: 196-206.

Salminen, R., M. J. Batista, M. Bidovec, A. Demetriades, B. De Vivo, W. De Vos, M. Duris, A. Gilucis, V. Gregorauskiene,
J. Halamic, P. Heitzmann, A. Lima, G. Jordan, G. Klaver, P. Klein, J. Lis, J. Locutura, K. Marsina, A. Mazreku, P. J. O'Connor, S. A. Olsson, R.-T. Ottesen, V. Petersell, J. A. Plant, S. Reeder, I. Salpeteur, H. Sandström, U. Siewers, A. Steenfelt \& T. Tarvainen, 2005. Geochemical Atlas of Europe. Part 1-Background Information, Methodology, and Maps. Association of the Geological Surveys of the European Union/Geological Survey of Finland, www.gtk.fi/publ/foregsatlas/.

Sas, H., 1989. Lake Restoration by Reduction of Nutrient Loading Expectations, Experiences, Extrapolation. Academic Verlag, St Augustin.

Schreiber, H., H. Behrendt, L. T. Constantinescu, I. Cvitanic, D. Drumea, D. Jabucar, S. Juran, B. Pataki, S. Snishko \& M. Zessner, 2005. Nutrient emissions from diffuse and point sources into the River Danube and its main tributaries for the period of 1998-2000 - results and problems. Water Science and Technology 51: 283-290.

Smith, V. H., 2003. Eutrophication of freshwater and marine ecosystems: a global problem. Environmental Science and Pollution Research 10: 126-139.

Smith, V. H., G. D. Tilman \& J. C. Nekola, 1999. Eutrophication: impacts of excess nutrient inputs on freshwater, marine, and terrestrial ecosystems. Environment Pollution 100: 179-196.

Søballe, D. M. \& B. L. Kimmel, 1987. A large-scale comparison of factors influencing phytoplankton abundance in rivers, lakes and impoundments. Ecology 68: 1943-1954.

Somlyódy, L. \& P. Shanahan, 1998. Municipal Wastewater Treatment in Central and Eastern Europe. Present Situation and Cost-Effective Development Strategies. World Bank, Washington.

Somlyódy, L., K. Buzás, A. Clement \& Z. Melicz, 1999. Strategies for approximating EU legislation in Hungary: the Sajó River case. Water Science and Technology 40: 87-94.

Stutter, M. I., B. O. L. Demars \& S. J. Langan, 2010. River phosphorus cycling: separating biotic and abiotic uptake during short-term changes in sewage effluent loading. Water Research 44: 4425-4436.

Swanson, C. D. \& R. W. Bachmann, 1976. A model of algal exports in some Iowa streams. Ecology 57: 1076-1080.

Thorp, J. H., M. C. Thoms \& M. D. DeLong, 2006. The riverine ecosystem synthesis: biocomplexity in river networks across space and time. River Research and Applications 22: 123-147.

Uherkovich, G., 1971. A Tisza Lebegô Paránynövényei (in Hungarian). Szolnok Megyei Múzeum Adattár, Szolnok, Hungary

Van Nieuwenhuyse, E. E. \& J. R. Jones, 1996. Phosphoruschlorophyll relationship in temperate streams and its variation with stream catchment area. Canadian Journal of Fisheries and Aquatic Sciences 53: 99-105.

Vannote, R. L., G. W. Minshall, K. W. Cummins, J. R. Sedell \& C. E. Cushing, 1980. The river continuum concept. Canadian Journal of Fisheries and Aquatic Sciences 37: 130-137.

Verasztó, C., K. T. Kiss, C. Sipkay, L. Gimesi, C. VadaiFülöp, D. Türei \& L. Hufnagel, 2010. Long-term dynamic patterns and diversity of phytoplankton communities in a large eutrophic river (the case of River Danube, Hungary). Applied Ecology and Environmental Research 8: 329-349. 
Vollenweider, R. A. \& J. J. Kerekes, 1982. Background and Summary Results of the OECD Cooperative Programme on Eutrophication. OECD, Paris.

Vörös, L., K. V. Balogh, S. Herodek \& K. T. Kiss, 2000. Underwater light conditions, phytoplankton photosynthesis and bacterioplankton production in the Hungarian section of the River Danube. Archiv für Hydrobiologie, Supplement band Large Rivers 11: 511-532.

Walks, D. J., 2007. Persistence of plankton in flowing water. Canadian Journal of Fisheries and Aquatic Sciences 64: 1693-1702. 